\title{
Experimentation of STAD and Jigsaw Learning Models on Learning Achievements in terms of Learning Motivation
}

\author{
Mela Dewi Putri Berlyana ${ }^{1,}$ Yunastiti Purwaningsih ${ }^{2}$
}

\begin{tabular}{l} 
ARTICLE INFO \\
\hline Article History: \\
Received 05.02.2019 \\
Received in revised form \\
28.05 .2019 \\
Accepted \\
Available online 01.10 .2019
\end{tabular}

\begin{abstract}
The purpose of this study was to compare the value of the pretest and posttest in the experimentation of the STAD and Jigsaw learning models on learning achievement in terms of learning motivation. This research is a quantitative research with an experimental method. The population of this study was all $X$ grade students of IPS of SMA Negeri 3 Boyolali in the Academic Year of 2017/2018with a total of 108 students, the study sample was determined by a cluster sampling technique of 2 classes with a total sample of 72 students. The learning model in the experimental class used the STAD method and the control class used the Jigsaw method. Data collection techniques in this study were the method of documentation, tests, and questionnaires. The research hypothesis test used two-way analysis of variance with a $2 \times 2$ factorial design and a significant level of $5 \%$. The analysis prerequisite test that is carried out is the normality test and homogeneity test using SPSS 23. From the results of the analysis it can be concluded that (1) differences in the effect of economic learning achievement between students who learn using STAD and Jigsaw cooperative learning models; (2) differences in the effect of learning motivation of students using STAD and Jigsaw cooperative models on economic learning achievement; (3) whether there is an influence of the interaction between the learning model and the learning motivation of students on economic learning achievement.
\end{abstract}

(c) IJERE. All rights reserved

Keywords: ${ }^{1}$

STAD, Jigsaw, Learning Achievement, Learning Motivation.

\section{INTRODUCTION}

Education consists of several components that are mutually integrated to form a system. In the education system there are several interrelated components, one of which is students. The success of education can be measured by the quality of students, so that many educational institutions always strive to improve their quality so that the quality of their students increases. Through a quality learning process students are prepared to be human beings who believe and fear God Almighty, have noble character, are healthy, knowledgeable, capable, creative, independent, and become democratic and responsible citizens, in accordance with national education goals (UU Number 20 of 2003). Therefore quality learning must be applied by educators in order to develop the potential of students to be personal in accordance with the objectives of national education. Learning is characterized by the interaction of students with educators and learning resources in a learning environment (Komara, 2014). Through a good learning process it is expected to be able to form students as national education goals, who have the knowledge, skills, character and attitude. But on the other hand there are various problems that can occur in the learning process. Problems that occur can originate from internal factors of students, including health, physical condition, intelligence, and interests, as well as from external factors, including the environment of students such as family, community, and school environment (Slameto, (2010:54). These factors can be a barrier to achieving educational goals, because it can be one of the causes of low learning achievement

\footnotetext{
1 mela.dewiputri94@gmail.com; orcid.org/0000-0002-3676-7882, Sebelas Maret University

2 orcid.org/0000-0003-4782-4819, Sebelas Maret University
} 
Based on the results of observations in class X IPS of SMA Negeri 3 Boyolali, it was found that there was a problem, namely the low learning achievement of students due to low interest in learning during the learning process, lack of motivation, students not actively studying and not doing work or assignments seriously. The value of students' understanding in understanding the material delivered by educators in the class is relatively low and has not yet reached KKM (Minimum Completeness Criteria) 75 with an average score of 73.5-73.7, students in the class were not active in learning where students are actively involved in learning only about $30 \%-40 \%$, the level of independence of the students described through the readiness of students before receiving the material by reading the material before learning takes place was also still relatively low only by $30 \%-45 \%$, the responsibility of students described through completeness in doing assignments, exercises in class, or homework can be said to be still low at $45 \%-50 \%$. Based on the data above, it can be assumed that the main problem faced by students is the low motivation to learn so that they are less eager to take part in classroom learning and their learning achievement are not optimal (Berlyana, M.,D.,P., 2017).

There are several ways that can be taken to do good and quality learning so that learning objectives that are part of curricular goals can be achieved. When the source of problems faced by students is motivation to learn, the teacher can present pleasant learning by involving students, giving students the opportunity to interact with the atmosphere of happiness and help each other in learning. Through fun activities, involving all parties, and in an atmosphere of togetherness that help each other, it is possible that the desire to be involved in the learning process will arise, and will spark the emergence of learning motivation of students. One way that can be taken is by applying the cooperative learning process.Cooperative learning is a teaching strategy designed to educate group cooperation and interaction between students (Janah, I., I., N, \& Subroto, W., T, 2018: 178). In this learning students work in groups and help each other to work together in maximizing learning conditions to achieve learning goals, so that each group member must be active in order to create the group's success.Cooperative learning models are developed not solely to achieve academic learning outcomes, but are also effective for developing social skills and collaboration skills. Cooperative learning is not only excellent in helping students understand difficult concepts, but also very useful to foster the ability to think critically, cooperate and help each other to solve a problem (Isjoni, 2010: 46). There are several cooperative learning models, namely Student Team Achievement Division (STAD), Jigsaw, Group Investigation (GI), and Structural Approach. Cooperative learning models that are able to increase motivation and learning achievement include STAD and Jigsaw Student Team (Mulyati, Anitah, Sunardi, 2013: 337-344; Jansoon, Samsook, \& Coll, 2008; Adams, 2013; Yusuf, Gambari , \& Olumorin, 2012).

The STAD learning model has several advantages including the interaction between students, mutual respect, and increasing intrapersonal skills. Besides that in applying the use of the STAD learning model, students who excel can become peer tutors for their friends who have not been able to understand the learning material (Khan and Inamullah, 2011: 212). The results of previous studies indicated that the use of STAD type cooperative learning model not only increases students' learning achievement but also can improve students' learning motivation. In addition, the use of STAD type learning model can encourage positive attitudes, produce better achievements and motivate students to learn (Wyk, 2012: 269). Through STAD cooperative learning model, students will be more active in finding and discovering their knowledge so that they can contribute to the success of their groups. The interaction between students has an impact that the knowledge gained by students is more meaningful because they are directly involved in the learning process.

Jigsaw is a cooperative learning model, where students learn in small groups consisting of 4-6 people heterogeneously. Learning material given to students in the form of text and each member is responsible for completing the part of the subject matter that must be learned (Slavin, 2005: 235). The Jigsaw type cooperative learning approach is a type of learning approach that emphasizes the concept of cooperative learning, where students are defined as social beings who need a group in learning or placed in a small community in the classroom (Yusnidar, 2016: 143 ). Jigsaw has been tested to be able to improve student learning achievement. In Jigsaw cooperative learning, students are actively involved in the learning process which will have a positive impact on the quality of interaction and communication and can motivate students to improve their learning achievement (Sulastri \& Rochintaniawati, 2009: 17).In addition, Jigsaw 
also has advantages that can develop behaviors and relationships among students to be better and can develop students' academic abilities that have an impact on improving their learning achievement.

\section{Problem Situtation}

The problem of not optimal learning achievement can be caused by various factors, including learning motivation of students. In order to improve student learning achievement, teachers can use the right learning model so that it can further motivate students to learn more actively and be actively involved in the learning process. Various learning models can be applied in order to increase students' motivation and learning achievement. In this study the STAD and Jigsaw cooperative learning models that were supposed to provide solutions (Berlyana, M.,D.,P., 2017). Therefore differences in the influence of the two models in terms of students' learning motivation towards learning achievement will be tested, in order to provide recommendations to teachers which learning models are more effective for students based on their learning motivation.

\section{The purpose of the Study}

The purpose of this study was to determine the differences in the influence of student learning achievement after applying the STAD and Jigsaw cooperative learning models in terms of students' learning motivation, including the implementation of STAD and Jigsaw cooperative learning models that can improve student learning achievement. In this objective framework, answers to the following questions have been searched, namely: differences in the influence of student learning achievement that apply the STAD and Jigsaw cooperative learning models in terms of learners' learning motivation.

\section{METHOD}

This research is a type of quantitative research with experimental research design. The independent variable in this study is the learning model and learning motivation, while the dependent variable is the economic learning achievement. The research design used in this study was a $2 \times 2$ factorial design. This experimental study aimed to examine and compare the relationship of certain variables to other variables in controlled conditions. This study will compare the differences in the value of pretest before treatment (using STAD and Jigsaw learning models) and posttest scores after treatment.

\section{Population and Sample}

The population in this study were students of class X IPS in SMA Negeri 3 Boyolali which consisted of 3 classes with a total of 108 students with 36 students in each class. Class sampling is done by using cluster sampling technique from class X IPS as many as 3 classes and selected 2 classes namely class X IPS 2 as experimental class and class X IPS 3 as heterogeneous control class regardless of gender, ethnicity, and level of performance (Sari, Ashadi, and Nugroho, 2013: 111). Both classes were grouped again based on the level of motivation to learn, namely high learning motivation and low learning motivation. According to Sardiman (2007: 83) students who have learning motivation include the following criteria: diligent in facing tasks, resilient facing difficulties, showing interest in various problems, preferring to work independently, be able to maintain their opinions, quickly get bored on tasks that routine or repetitive, it is not easy to let go of the thing that is believed, and love to find and solve questions.

\section{Data Collection Technique}

There are 3 data collection techniques used in this study, namely (1) the documentation method used to obtain data on the number and name list of students, as well as to determine the ability of the initial experimental class and control class before being given treatment that can be seen from the previous semester grades/scores of economic test, (2) the test method used to measure the ability of students in the form of economic learning achievement, (3) the questionnaire method in the form of written questions used to obtain information about learners' learning motivation.

\section{Data Analysis}

The data analysis technique in this study used a two-way variance analysis, carried out using SPSS 23. Prior to the analysis, a preliminary analysis of variance analysis was carried out, namely the normality test and homogeneity test. The data of normality test aims to determine whether the data obtained from the research results are normally distributed or not. The normality test in this study used the Liliefors test with a 
significance level of $5 \%$. Homogeneity test is used to determine whether the variances of a number of populations are the same or not. The method used for homogeneity test is the Bartlett method with a significance of $5 \%$.

\section{FINDINGS}

Test requirements analysis is needed to find out whether the data analysis for hypothesis testing can be continued or not. Some data analysis techniques require test analysis requirements. Variance analysis requires data from populations that are normally distributed and homogeneous compared groups. Therefore analysis of variance requires a test of normality and homogeneity of the data (Hidayat, 2010: 1-3).

The calculation results of the comparison of the pretest and posttest scores on the experimentation of the STAD and Jigsaw learning models on learning achievement in terms of learning motivation, are presented in table 1 .

Table 1. Comparison of pretest and posttest

\begin{tabular}{rrrrrr}
\hline $\begin{array}{r}\text { Learning } \\
\text { Achievement }\end{array}$ & $\begin{array}{r}\text { Numbe } \\
\text { r of Students }\end{array}$ & $\begin{array}{c}\text { Mini } \\
\text { mum }\end{array}$ & $\begin{array}{c}\text { Maxi } \\
\text { mum }\end{array}$ & $\begin{array}{c}\text { Aver } \\
\text { age }\end{array}$ & $\begin{array}{c}\text { Stand } \\
\text { ard } \\
\text { Deviation }\end{array}$ \\
\hline Pretest & 72 & 40 & 90 & 66,39 & 14,56 \\
Postest & 72 & 45 & 100 & 77,71 & 14,19 \\
\hline
\end{tabular}

Source: the results of SPSS data processing

The summary of the two-way variance analysis test results on the experimentation of the STAD and Jigsaw learning models on learning achievement in terms of learning motivation, is presented in Table 2.

Table 2. Description of Statistics Two-way variant analysis on the experimentation of the STAD and Jigsaw learning models on learning achievement in terms of learning motivation

\begin{tabular}{ccccc}
\hline $\begin{array}{c}\text { Learning } \\
\text { Model }\end{array}$ & $\begin{array}{c}\text { Motivat } \\
\text { ion }\end{array}$ & $\begin{array}{c}\text { Number of } \\
\text { Students }\end{array}$ & Average & $\begin{array}{c}\text { Standar } \\
\text { t Deviation }\end{array}$ \\
\hline Jigsaw & Low & 14 & 56,79 & 9,12 \\
& High & 22 & 80,91 & 7,34 \\
\cline { 2 - 5 } & Total & 36 & 71,53 & 14,33 \\
\hline \multirow{2}{*}{ STAD } & Low & 16 & 75,00 & 9,13 \\
& High & 20 & 91,00 & 6,61 \\
\cline { 2 - 5 } & Total & 36 & 83,89 & 11,16 \\
\hline
\end{tabular}

Source: the results of SPSS data processing

Based on table 2. it is known that the STAD group obtained a total score of 83.89 and in the Jigsaw group obtained a total score of 71.53, so it can be concluded that the STAD group was better than the Jigsaw group.

Table 3. The results of the Two-Way Variant Analysis Test on the experimentation of the STAD and Jigsaw learning models on learning achievement in terms of learning motivation.

\begin{tabular}{cccccc}
\hline & $\begin{array}{c}\text { Numbe } \\
\text { rof } \\
\text { Quadrants }\end{array}$ & $\begin{array}{c}\text { Fre } \\
\text { e Degree }\end{array}$ & $\begin{array}{c}\text { Averag } \\
\text { e Squared }\end{array}$ & $\begin{array}{c}\text { Freq } \\
\text { uency }\end{array}$ & $\begin{array}{l}\text { Probability } \\
\text { Value }\end{array}$ \\
\hline Corrected & 10004,7 & 3 & 3334,9 & 52,8 & 0,000 \\
Model & 402080, & & 402080, & 6370, & 0,000 \\
Intercept & 7 & 1 & 7 & 1 & 0,000 \\
Method & 3492,8 & 1 & 3492,8 & 55,3 & 0,000 \\
Motivation & 7018,3 & 1 & 7018,3 & 111,2 & 0,036 \\
Method & 287,7 & 1 & 287,7 & 4,6 &
\end{tabular}


Motivation

\begin{tabular}{llll} 
Error & 4292,2 & 68 & 63,1 \\
& 449075, & & \\
Total & 0 & 72 & \\
\hline
\end{tabular}

Source: the results of SPSS data processing

The two-way analysis of variance tests on the effect of the STAD and Jigsaw learning models on achievement in terms of learning motivation produced a significance level of $p=0.036(p<0.05)$. It can be seen that there is an interaction between the learning model and learning motivation towards student learning achievement where students become more motivated in learning that applies the STAD type cooperative learning model.

\section{DISCUSSION}

Based on the results of statistical tests using SPSS 23 it can be seen that the average posttest scores of academic learning achievement in economic subjects has increased. The average scores at 66.39 pretest increased to 77.71 using the STAD and Jigsaw cooperative learning models. Improvement of student learning achievement is due to the application of learning models that are suitable for economic subjects. Economic subjects are branches of social science arranged through education so that the transfer of concepts can develop and train attitudes, values, morals, and skills of students in achieving meaningful life (Sapriya, 2014: 7). This is in accordance with the concept of the STAD learning model which emphasizes the existence of activities and interactions among students to motivate each other and help each other in mastering the subject matter in order to achieve maximum learning achievement. According to Sihwinedar (2015), the application of appropriate learning can support a conducive learning climate so that students will have meaningful learning experiences and in turn, can develop their intellectual skills.

The results showed that students who applied the STAD learning model along with high learning motivation gained better learning achievement than students who applied the Jigsaw learning model along with high learning motivation. By applying the appropriate learning model accompanied by high learning motivation in students can improve their learning achievement. Wyk (2012) suggested that the learning achievements obtained by students had increased as a result of the use of the STAD learning model. This is because in STAD learning model students can work together with a team/group so that they can discuss in solving a problem in the subject matter and students can motivate each other because students groups are formed heterogeneously, the clever students can help students who are less clever so that they can understand the whole subject matter.

Another finding in this study was that there is an increase in student motivation after educators apply the STAD and Jigsaw learning models on economic subjects. The STAD learning model has an interesting learning atmosphere, proven by the collaboration between students so that the material provided can be understood comprehensively. Whereas the class with the Jigsaw learning model also has similarities with the STAD learning model which makes the learning atmosphere attractive as the students' enthusiasm in following the learning process is proven by students who work together in groups (Lukman, Rindarjono, Karyanto, 2016: 118- 119). The similarity of research conducted by Wyk and the researcher lies in the situation and condition of students in the classroom where students tend not to study hard and have a low level of understanding of learning material.

Implementation of the STAD learning model can improve student learning achievement, this is because STAD learning model is one of the cooperative learning strategies that emphasize learning activities in students (Student Center). In addition, the application also directs students to be actively involved in learning to solve problems that exist in the material that being studied. Students who do not understand the material will be assisted by their group members in order to understand the learning material, with the collaboration between students, the learning material will be comprehended comprehensively and can foster learning motivation for students and improve their learning achievement. In STAD learning model, students can work together with a team or group so that they can discuss in solving a problem in the subject matter and students can motivate each other because students groups are formed heterogeneously, who are clever can help students who are less clever so they can understand the overall subject matter (Wyk, 2012). In addition, the implementation of the Jigsaw learning model is also a cooperative learning that prioritizes 
cooperation and interdependence between students and is based on a constructivist view where knowledge is built on the knowledge of the learners themselves (Asfaroh \& Hidayati, 2014: 3). The difference with the STAD learning model is that in the Jigsaw learning model, students in each group member are assigned randomly to become "experts" in a small part of the overall learning material and then will teach it to other students in the group.

Through the application of the STAD learning model, students become more motivated in learning so that they can improve their learning achievement. Basically every student has the motivation to learn. Learning motivation possessed by students varies, there are those who have high learning motivation, there are also students who have low learning motivation. Learning motivation of students is an important component in learning. Without the motivation to learn, the process and learning objectives will be difficult to sustain. Learning motivation can foster a spirit of learning so students are encouraged to carry out learning activities. Students who have high learning motivation will do learning activities with feelings of pleasure and without force so that they can improve student learning achievement.

The difference in learning achievement of applying both learning models can be seen in the results of the two-way ANOVA test. The results showed that there was an influence of the learning model applied to the economic learning achievement of students in SMA Negeri 3 Boyolali, so that there were differences in economic learning achievement between students who studied with learning models from STAD and Jigsaw learning models. The difference can also be seen from the average value of economic learning achievement. Learning achievement of students after applying the STAD learning model has an average scores of 83.89 which is higher than the class that applies the Jigsaw learning model which has an average scores of 71.53.

The study found that the class with the STAD learning model was better able to improve student learning achievement in economic subjects compared to classes with the Jigsaw learning model. Students can learn actively in learning and work together to help other students in the group to be able to understand the learning material. In STAD cooperative learning educators act as facilitators and motivators in learning to help improve student learning achievement. This is done so that students can socialize and interact with each other so that they can motivate students to be able to support each other and help other students to understand the subject matter so that it will improve their learning achievement. The implementation of the STAD learning model is effective for increasing learning motivation, because in the process students conduct discussions, are able to form a group work, and solve problems, so that students can perform optimally. Students who have high learning motivation always show high curiosity towards the subject matter given and try to understand the subject matter as a whole so that they have higher learning achievement compared to students who have low motivation. Students who have low motivation in learning are only as good as possible without a deeper curiosity about the subject matter (Mulyati, Anitah, Sunardi, 2013).

The results of this study are in line with research conducted by Adesoji and Ibraheem (2009), Wyk (2012), Khan and Inamullah (2011). The results of the research stated that the STAD learning model not only can improve the achievement of students' learning achievement, but also can increase students' learning motivation. The STAD learning model has a superior influence and has advantages to improve student learning achievement compared to the Jigsaw learning model.

The advantage of the STAD learning model lies in the characteristics of each learning step. The steps are to form heterogeneous study groups according to their level of performance, gender and ethnicity consisting of 4-5 people. Each group member works together to achieve learning goals (Sari, Ashadi, and Nugroho, 2013; Majoka, Dad, and Mahmood, 2010; Tiantong and Teemuangsai, 2013). It is expected that interactions between students and mutual respect can increase intrapersonal skills. In addition, in the application of the use of the STAD learning model students who excel also become peer tutors for their friends who have not been able to understand the learning material and can also increase learners' motivation (Khan and Inamullah, 2011).

The STAD learning model is active, fun and accompanied by emphasis on the interaction of learners in learning making learning centered on students which will make it easier for students to understand learning material and ultimately improve learning achievement. There are several weaknesses in the STAD learning model including the contribution of low achieving students to less and the disappointment because the role of the clever members is more dominant. In addition, when compared to the Jigsaw learning model, there is 
also a weakness, that is, if one participant does not read the assignment, the information cannot be shared or discussed. Moreover for learning that is narrative in various information. Learning motivation is an impulse that arises in students to learn so that students will be more enthusiastic and voluntary without any compulsion in learning. High learning motivation will improve student learning achievement. Motivation for achievement has a big influence on a person's performance, including learning, learning will be faster and better if they have goals to be achieved. Someone who has high achievement motivation will tend to complete his task without delay, study diligently, and try to achieve his goals (Hamzah, 2011). In this case students will get high learning achievement if they have high learning motivation and are supported by the right learning model.

\section{CONCLUSION AND SUGGESTION}

Based on the results of the data analysis and discussion it was concluded that the application of the STAD learning model in learning was more significant for improving economic learning achievement in terms of students' learning motivation in SMA Negeri 3 Boyolali. Students who apply the STAD learning model have higher learning achievement than the class that applies the Jigsaw learning model. In addition, this study shows that students who have high learning motivation will also get high learning achievement when compared with students who have low learning motivation. Based on the results of the study, there are a number of suggestions for further research including suggestions to principals of the schools to encourage educators to apply cooperative learning to each subject and provide motivation and encouragement to educators to participate in activities that can increase their knowledge so that they can do varied learning.Suggestions for educators are that in implementing the STAD and Jigsaw cooperative learning models, they should be well prepared so that learning can run smoothly and in accordance with expectations, educators must prepare an orderly and conducive atmosphere in the classroom so that it can influence students' learning motivation which will affect their learning achievement, besides that educators must also be more creative and innovative in the learning process so that students be more interested in learning and more easily receive the learning material. In addition to advice to principals and educators there are also suggestions to students as follows, namely that students should actively participate in the learning process and pay close attention when given an explanation by educators nor other students, both in group discussions and presentations in front of the class, students should prepare themselves before participating in the learning process by learn the material to be discussed first, active in the learning process, and students should have a high learning motivation because with the learning motivation of students who apply the STAD learning model will be better than the learning motivation of students who apply the Jigsaw learning model. Educators are expected to use a learning model that can improve students' learning motivation, so that their learning achievement increases. This research has been maximally attempted but there are still factors that are difficult to control so that in this study there are still some limitations. These limitations include, for example, a short research time that allows the treatment effect to not reflect student learning achievement to the fullest, the results of the study cannot be generalized to different research subjects, and the experimental research design requires the control of all research variables outside the predetermined variables so that does not interfere with the treatment process in the experiment.

\section{References}

Asfaroh, J. A. \& Hidayati. (2014). Pengaruh Penerapan Model Pembelajaran Kooperatif Tipe Jigsaw dan Tipe Think Pair Share terhadap Hasil Belajar IPA Siswa Kelas VII SMP Taman Dewasa Ibu Pawiyatan Tahun Ajaran 2012/2013, Jurnal Pendidikan IPA Natural, 1 (1), 1-73. Retrieved from http://journal.ustjogja.ac.id/download/jurnal\%20nat\%20edit\%20hal\%209.pdf.

Adams, F. H. (2013). Using Jigsaw technique as an effective way of promoting cooperative learning among primary six pupils In Fijai. International Journal of Education and Practice. 1, 64-74. Retrieved from http://www.aessweb.com/pdf-files/ijep\%201(6),\%2064-74.pdf.

Berlyana, M., D., P, (2017). Kriteria Ketercapaian Tujuan Pendidikan Mata Pelajaran Ekonomi Kelas X IPS SMA Negeri 3 Boyolali Tahun Ajaran 2017/2018. Universitas Sebelas Maret.

Hidayat, A. (2010). Metode Penelitian Kesehatan Paradigma Kuantitatif. Jakarta:Health Books.

Hamzah, B. (2007). Teori Motivasi \& Pengukurannya. Jakarta: Bumi Aksara.

Isjoni. (2010). Cooperative Learning. Bandung: CV Alfabeta. 
Janah, I., I., N, \& Subroto, W., T, (2018). Comparison of cooperative learning models with inquiry on student learning outcomes. International Journal of Educational Research Review, 4(2):178-182. Retrieved from https://www.ijere.com/frontend//articles/pdf/v4i2/8pdf.pdf.

Jansoon, N., Samsook, E., \& Coll, R. K. (2008). Thai undergraduate chemistry practical learning experiences using the Jigsaw IV Method. Journal of Science and Mathematics Education in Shoutheast Asia, 31 (2), 178-200.

Khan, G. N. \& Inamullah, H. M. (2011). Effect of student's team achievement division (STAD) on academic achievement of students. Asian Social Science, 7 (12), 211-215. doi:10.5539/ass.v7n12p211.

Komara, E. (2014). Belajar dan Pembelajaran Interaktif. Bandung:.Aditama.

Lukman, S., Rindarjono, M. G., \& Karyanto, P. (2016). Pengaruh Model Pembelajaran Kooperatif Tipe Jigsaw dan STAD Terhadap Hasil Belajar Geografi Ditinjau Dari Motivasi Belajar Siswa Kelas VIII SMP Negeri Jatinom Klaten Tahun Pelajaran 2013/2014. Jurnal GeoEco, 2 (2), 114-127.

Mulyati, Anitah, S., \& Sunardi. (2013). Pengaruh Penggunaan Model Pembelajaran Kooperatif Tipe STAD dan Tipe Jigsaw Terhadap Prestasi Belajar Ilmu Pengetahuan Sosial Ditinjau Dari Motivasi Siswa. Jurnal Teknologi Pendidikan dan Pembelajaran, 1 (3), 337-344.

Rohmat., Hakim, L., \& Sakti, N. C. (2019). Implementation of Jigsaw type cooperative learning model to improve economics learning results. International Journal of Educational Research Review, 4 (2): 350357. Retrieved from https://www.ijere.com/frontend//articles/pdf/v4i3/template-ijererohmatpdfpdf.pdf.

Saat, S. (2015). Faktor-faktor Determinan dalam Pendidikan (Studi Tentang Makna dan Kedudukannya dalam Pendidikan). Jurnal Al-Ta'dib, 8 (2), 1-17.

Sapriya. (2014). Pendidikan IPS. Bandung: Remaja Rosdakarya.

Sadirman, A. M. 2007. Interaksi dan Motivasi Belajar Mengajar. Jakarta: Rajawali Pers.

Sari, A. P., Ashadi., \& Nugroho, A. 2013. Studi Komparasi Model Pembelajaran STAD dengan Menggunakan Media Animasi Macromedia Flash Player dan Molymod pada Pembelajaran Kimia Materi Pokok Ikatan Kovalen Ditinjau dari Kreativitas Siswa Kelas X SMA N 2 Sukoharjo Tahun Pelajaran 2011/2012. Jurnal Pendidikan kimia, 2 (2), 110-116.

Sihwinedar, R. (2015). Meningkatkan hasil belajar IPA melalui penerapan model Pembelajan SAVI (Somatis, Auditori, Visual, dan Intelektual) pada siswa kelas III SDN Rejoagung 01 Semboro Tahun pelajaran 2013/2014. Jurnal Pancaran Pendidikan, 4(4): 137-148.

Slameto. (2010). Belajar dan Faktor-faktor yang Mempengaruhinya. Jakarta: Rineka Cipta.

Slavin, R. E. (2005). Cooperative learning: Teori, Riset dan Praktik. Bandung: Nusa Media.

Sulastri, Y. \& Rochintaniawati, D. (2009). Pengaruh Penggunaan Pembelajaran Kooperatif Tipe Jigsaw dalam Pembelajaran Biologi di SMP N 2 Cimalaka. Jurnal Pengajaran MIPA, 13 (1), 15-20. doi: http://dx.doi.org/10.18269/jpmipa.v13i1.302.

Sugiarto, S. \& Suhendra, R. (2018). Pendampingan Terhadap Guru Sekolah Menengah Pertama Mengidentifikasi Masalah Belajar Siswa Pada Mata Pelajaran Bahasa Indonesia. Jurnal Kependidikan, 2 (2):12-18.

Suwandi, S. (2016). Pedoman Tesis dan Disertasi Pascasarjana Kependidikan Fakultas Keguruan dan Ilmu Pendidikan. Surakarta: UNS Press

Undang-Undang RI. No. 20 Th. (2003). Undang-Undang Sisdiknas (sistem Pendidikan Nasional) 2003.Cet. II; Jakarta: Sinar Grafika, 2005.

Wyk, M. V. (2012). The effects of the stad-cooperative learning method on student achievement, attitude and motivation in economics education. Journal Social and Science, 33 (2), 261-270. doi: 10.1080/09718923.2012.11893104.

Yusnidar. (2016). Pendekatan Metode Kooperatif Type Jigsaw untuk Meningkatkan Kemampuan Belajar Siswa Materi Tentang Memahami Hadist Tentang Menjaga dan Melestarikan Lingkungan Alam. Jurnal Visipena, 2 (2), 138-156.

Yusuf, M. O., Gambari, I. A., \& Olumorin, C. O. (2012). Effectiveness of Computer-Supported Cooperative Learning Strategies in Learning Physics. International Jurnal Social, Science, \& Education, 2 (2), 94-109. 